\title{
Introduction
}

Personalising menopausal healthcare with tailored information and shared decision making between the health professional and woman is the ideal. This should begin before the menopause transition. This review will explore the evolving opportunity that the Internet affords in enabling this process.

Over the past decade, the management of woman's healthcare has changed from the alleviation of menopausal symptoms to include the management of other lifechanging medical issues falling under the aegis of post-reproductive health; A lifecourse approach ${ }^{1}$ aimed at both maximising health and minimising, if not preventing, negative sequelae in this third stage of a woman's life, provides an important framework for care. This framework is recognised by the Royal College of Obstetricians and Gynaecologists as a standard in which to understand and mitigate against the long-term effects of earlier biological, behavioural and social exposures. A life-course approach in women's health also acknowledges gender-specific medicine.

Gender-specific medicine is the study of how diseases differ between men and women in terms of prevention, clinical signs, therapeutic approach, prognosis, psychological and social impact - it is a neglected dimension of medicine. ${ }^{2}$ Gender differences in susceptibility to complex diseases; e.g. asthma, diabetes and depression, come under the umbrella of epigenetics. ${ }^{3}$ Epigenetics is the study of factors which control gene expression other than the genetic code itself, and epigenetic markers have been shown to be passed on to children and grandchildren ${ }^{4}$ 
challenging the paradigm that disease caused by lifestyle can have no effect on offspring. The Barker hypothesis ${ }^{5}$ was a forerunner to epigenetics and proposed programming in utero and in infancy as a mechanism for later poor health. Links are well established between reduced birth weight and increased risk of coronary heart disease, diabetes, hypertension, and stroke in adulthood. The possibilities of understanding these complex relationships are being explored in the emerging fields of systems biology ${ }^{6}$ and Big Data analytics". Mitigating against this "toxic" information and other future diseases that have epigenetic origins fits within a lifecourse framework, not least maximising post reproductive health. ${ }^{8}$ The Internet is expected to be increasingly utilised as a tool for pathological and biological testing. Direct to consumer genetic testing is already available and the market is expected to grow and to date, negative effects on consumers or health benefits have yet to be observed. $^{9}$

The future of medicine is increasingly being mediated through preventative, participatory, personalised, and predictive (P4) modes. It is, by necessity, changing from a reactive model to a preventative patient-centric one with information and communication technologies (ICTs) playing an increasing role. $^{10}$

There is also a move from solely a biomedical model of healthcare to a biopsychosocial model. ${ }^{10}$ which recognises that in addition to the biomedical model, psychological, social, environmental and cultural factors all can impact on human functioning in the context of disease and illness. The western biomedical paradigm targeted principally at treating infectious diseases has been effective in delivering health care, but this model is not positioned to tackle the complex societal challenges or solve the current problems facing health care and delivery caused by 
ageing populations with increased incidence of long term/chronic conditions and globalisation. The biopsychosocial model is a call to change the way of understanding the patient and to expand the domain of medical knowledge to address the needs of each patient.

Within this latter model is recognition that "one size does not fit all" and that evidence based medicine from randomised controlled trials does not always easily translate into clinical practice. ${ }^{11}$ One of the reasons preventing this transition of practice from trials to bedside is the patient's psychosocial circumstances. It is therefore incumbent on health professionals to recognise this and tailor treatment and management plans accordingly. Providing healthcare in an increasingly patientcentred way allows the achievement of preferable health outcomes. The health professional-patient relationship therefore is increasingly a shared model of decision making in the preferred outcomes process. ${ }^{12}$ This can be thought of as personalisation of healthcare in which a dialogue takes the best medical evidence and information available and creates a management plan that fits with the patient's lifestyle and preferences. ${ }^{13}$ This personalisation may be a compromise on best medical evidence in order to accommodate the patient's wishes. This preferred health outcome differs from possible (might it happen), plausible (could it happen) and probable (how likely is it to happen) outcomes. The preferred model emphasises the woman's co-participation in exploring all the evidence and options for the management of a condition and the implications thereof. This evidence and options are increasingly being influenced by ICTs utilising the World Wide Web and the Internet (Table 1). ${ }^{14}$ 


\section{The World Wide Web}

The World Wide Web (The Web) is a compilation of documents and other web resources, linked by hyperlinks and Uniform Resource Locators or URLs. The Web went live in March 1989 and is already the largest human information construct in history transforming societies everywhere. The Internet, a system of computer networks, which the Web uses as the conduit to access information, has been around since the 1960s. The Web has evolved from Web 1.0, focused on simple non-interactive documents, to Web 2.0, utilising the tools of interactivity and social space. Health related technology has followed suit, i.e. Health 1.0, Health 2.0, Medicine 2.0, however, no consensus regarding their definition exists. ${ }^{15}$ It is without question that the Web is dynamic and evolving, with interactivity at its core. Web 3.0, knowledge and reasoning systems also known as the semantic web and web of linked data, is at the beginning of its evolution and aims to allow computers to understand and respond to the meaning of complex human requests through linking of multiple disparate databases.

\section{Menopause and the Web}

In a review published 10 years ago in the Journal of the British Menopause Society 'The Internet and the menopause consultation: menopause management in the third millennium, ${ }^{, 16}$ seven ways were suggested in which the Internet could be used in the menopause consultation (Table 2).

From a global perspective, all these have occurred to a greater or lesser extent in the management of the menopause. Table 3 shows a comparison of traditional and 
new ways of delivering healthcare using the Internet and provides advantages and disadvantages of new possibilities.

\section{www.menopause matters.co.uk as an exemplar of menopause management}

The website www.menopausematters.co.uk is patient-tailored, physician-led. The website went live in 2002 and has steadily grown in popularity, reflecting both the increasing interest in web-based health information and the increased access and computer literacy of the public. The site aims to educate women and health professionals and to empower and enable women to take a more active part in the management of their menopause. Their discussion with their health professional then increasingly becomes a shared process by incorporating the first 5 points in Table 2. The website was created in consultation with end-users through feedback questionnaires. Through online surveys, the website aims to obtain "snapshots" of Internet literate women's views on all aspects of their menopause experiences and provide feedback to them and their health professionals.

www.menopausematters.co.uk surveys have consistently demonstrated that women are reluctant to seek help for reduced libido, ${ }^{17}$ vaginal atrophy, ${ }^{18}$ dyspareunia ${ }^{18}$ and urinary incontinence ${ }^{19}$ despite adverse effects on health and wellbeing. Furthermore, a large number of women who obtained information from health professionals and the Internet felt that they did not have enough information to make informed decisions regarding the use of HRT and alternative therapies. Additionally, health professionals frequently fail to explore these areas during consultations despite proven treatments being available. Preliminary evidence has also suggested the power of the media through digital online storytelling to empower women to seek 
help for vaginal atrophy. ${ }^{20}$ The power of the media was shown in a survey ${ }^{21}$ which suggested that younger women were more susceptible to negative media reports concerning HRT than older women. www.menopausematters.co.uk continues to strive to be accessible to women and health professionals promoting evidence based practice and recommendation and encouraging them to be proactive in their care.

\section{The next step in menopause advice - tailoring the information to the woman}

While www.menopausematters.co.uk allows health professionals and women to select expertly prepared information (Web1.0) or interact with one another (Web 2.0) via the forum it is limited with respect to personalisation. The main aims of www.managemymenopause.co.uk are to provide more personalised healthcare advice that empowers women to make informed choices about symptom management and risk factor modification underpinned by expertly prepared information. www.managemymenopause.co.uk utilises a patient questionnaire and three risk prediction tools to generate a tailored advice document that provides risk advice and information on lifestyle modification and pharmacological interventions both hormonal and non-hormonal. As users have directly participated in the generation of the advice document, it is hoped they will be motivated to use the information provided to facilitate a discussion with a healthcare provider about symptom control and to make the necessary lifestyle modifications that will help prevent future disease. This UK website went live in November 2015 to coincide with the release of the first UK NICE menopause guideline ${ }^{22}$ highlighting individualised care. The website will "remember" a woman and can therefore tailor the information to the woman as she ages or as the information underpinning the management of menopause changes. 


\section{Tailoring information Postmenopause}

The benefits of seeking online health information and participatory Internet use have generally focused on young or middle aged women. The postmenopausal age group is increasingly technologically literate. These developments are particularly timely as older women have an increased risk of chronic illnesses. For this group access to interactive health information on the Web holds particular promise. ${ }^{23}$ Older women, and particularly those with mobility limitations impacting visits to physicians, can pose particular challenges. Availability of web-based communication with health care providers will thus increasingly offer health benefits. ${ }^{24}$

The opportunities for healthcare and its delivery in the Internet age can be formulated as in Figure 1, underpinned by the disciplines of Health Web Science and Medicine 2.0.

\section{Health Web Science \& Medicine 2.0}

Health Web science is a sub-discipline of Web Science ${ }^{25,26,27}$ that complements and overlaps with disciplines under the aegis of Medicine 2.0. In short, Health Web Science studies the role and impact of the Web on health and well-being and conversely the impact of health related uses of the design of the Web structure and evolution that explicitly includes an alliance with nonmedical stakeholders. Medicine 2.0 or next generation medicine enabled by emerging technologies (Eysenbach, 2014, introductory talk to Medicine 2.0 Malaga), on the other hand, arguably emphasises anything that uses the Internet as a conduit to deliver health care. As 
the tools of Web 3.0 evolve it will become possible to interrogate different sources of data to achieve more robust answers to individualised health care questions.

\section{Health Web Observatory}

The Web Science Trust hosted by the University of Southampton is a charitable body which supports the global development of Web Science. ${ }^{28}$ The Trust .introduced the concept of a Web Observatory ${ }^{29}$ as an integrated collection of data sources and data analysis tools that enable observation and experimentation for Web study. ${ }^{30}$ The Web Science Trust has further positioned a web observatory to bridge the gap between Big data and the rapidly growing web of Broad data. ${ }^{31}$ This distinction between Big data and Broad data is important. Analysis and conclusions from Big data on a subject may come from one source only, whereas analysis and conclusions from Broad data on a subject come from many data sources. This enables triangulation and increasing the veracity of the conclusions. A Health Web Observatory therefore is a system that links to and gathers health and usage data on the Web (Big data and Broad data) in order to answer questions about the web, the

users of the Web, and the way that each affects each other within the domain of health related uses.

\section{Internet health provision}

Health Web Science, Medicine 2.0 and Health Web Observatories have potential to be major catalysts in the evolution of Internet health. Internet health is a broad term that encompasses telemedicine, e-health (the transfer of health resources and 
healthcare by electronic means) and mobile health (m-health):- the use of wireless technology to deliver health services and information using mobile communication devices such as tablet computers, smart phones and other monitoring devices. ${ }^{32}$ Monitoring devices that are beyond the scope of this article are becoming more ubiquitous i.e. both external (including environmental) and internal with selfmonitoring a growing part of P4 medicine.

Virtual clinics are becoming increasingly utilised within the NHS. These are in lieu of face to face contact and can take a number of forms. ${ }^{33}$ A novel evolution of virtual clinics using digital technology to deliver and facilitate patient engagement with health provision is NHS Grampian's No Delays ${ }^{34}$. This concept uses video on demand to provide personalised patient postcards. No Delays aims to transform outpatient services by helping people to take responsibility for their own care, provide care as close to home as possible and reduce the need for attendance at hospital clinics or unscheduled admission to hospital. The No Delays platform is not a static website but a dynamic resource that allows clinicians to work interactively with patients to improve understanding of their condition and/or treatment. No Delays allows healthcare teams to digitise elements of their local care pathway by creating interactive packages of digital content that can be personalised by healthcare professionals and prescribed to patients according to their needs.

\section{Economics of Internet health provision}

Implementing the UK's Delivering Assissted Living Lifestyles at Scale (dallas) programme and the lessons learned from it provide a useful framework in which to implement digital healthcare tools and services at scale. ${ }^{35}$ In a review of cost utility 
and cost effectiveness of Internet health provision ${ }^{32}$ the authors concluded that due to methodological flaws economic evaluations are limited due to disparate estimation methods, lack of randomised controlled trials, lack of long term evaluation studies, small sample sizes and absence of quality data and appropriate measures. Similar conclusions were reached in a Norwegian review ${ }^{36}$ which observed that despite a limited number of large-scale services and sparse evidence e-health is costeffective, interest in e-health continues to grow. This continuous interest might be explained by the promise of e-health to solve some of the pressing problems in health care.

\section{Future}

Using the tools of Medicine 3.0, the disciplines of Medicine 2.0 and Health Web Science, and the technology underpinning Web Observatories, the ambition is to provide a framework to build an integrated online social network for women's health. This network will be populated by women, health professionals and health related sites that are capable of being linked to each other for further study. Thus, these data sources will be able to be interrogated to personalise healthcare questions, and then through dialogue and traditional medicine, plan a preferable health outcome. Health professionals in primary and secondary care will provide increasingly personalised care supporting patients to develop the knowledge and skills to become active partners in their own healthcare using the information from these evolving decision aids. ${ }^{37}$ New tools and metrics will need to be developed to assess the impact of these technologies on health outcomes.

\section{Conclusion}


The recently published NICE guidelines have supported individualized care. ${ }^{38}$ The Royal College of Obstetricians and Gynaecologists (RCOG) life-course framework encourages predictive, preventative, participatory and personalization of healthcare. Using this framework, management of the post-reproductive epoch starts well before the menopause transition. Shared decision making towards a woman's preferred health outcome can be a compromise between best medical evidence and a woman's choice. ICTs have an increasing role to play in healthcare. Health Web Observatories informed by the disciplines of Medicine 2.0 and Health Web Science have potential to deliver individualised medicine of the future. More research is needed to evolve the tools to assess the impact of ICT on healthcare and its delivery. Health professionals will increasingly support patients to be active partners in their own care. The cost effectiveness of these interventions also need to be addressed

www.menopausematters.co.uk will continue to survey women's experience of the menopause and continue to address how to improve both women and health professional knowledge of the menopause.

www.managemymenopause.co.uk will continue to personalise healthcare and refine its ability to be specific for that individual.

In the Journal of the British Menopause Society 2005 paper we concluded that the transfer of health resources and health care by electronic means (ehealth) has the potential to be a union made in heaven between man and machine. We still believe that. 


\section{Acknowledgement}

We would like to thank Dr Douglas McKendrick, consultant anaesthetist, Dr Grays Hospital for "formulating" healthcare,Dr Heather Currie, Dumfries \& Galloway Royal Infirmary, the CEO of www.menopausematters.co.uk for her advice on the manuscript and Dr Jamie Hogg, Clinical Lead for Modernisation NHS Grampian for his advice on No delays.

The authors comprise a multidisciplinary, international team reflecting the collaboration required to deliver healthcare in the $21^{\text {st }}$ century and in particular postreproductive healthcare utilising the power of the Internet. The team therefore represents computer scientists, gynaecologists with an interest in menopause, a designer with a psychology background and a medical sociologist specialising in aging. The team epitomises the collaboration required to make Health Web Science and Medicine 2.0 possible. The authors have previously published in the areas of menopause, Health Web Science and Medicine 2.0.

Box 1 What users do online ${ }^{11}$

$66 \%$ look for information about a specific disease or medical problem
$54 \%$ ask doctor new question or get a second opinion from another
$36 \%$ affected their decision whether or not to visit the doctor
$58 \%$ say the advice has improved the way they take care of themselves
$55 \%$ say access has improved the way they get health information
$24 \%$ female users look for information about pregnancy and childbirth
$70 \%$ say information has influenced their decision how to treat an illness
$27 \%$ have monitored a health parameter online
$4 \%$ have posted their experience with a drug or treatment
$24 \%$ consulted online reviews of particular drugs or treatments
$44 \%$ look for information about doctors or other health professionals
$15 \%$ have consulted online rankings or reviews of hospitals or other medical
facilities


Box 2. Potential role of the Internet in facilitating the menopausal consultation.

1 as a resource for additional information or support before or after a visit to a health professional;

2 as a resource during a visit to health professional;

3 for online support groups and forums;

4 as an intervention;

5 as a resource for consultation between specialist and generalist;

6 for online consultation

7 for prescribing. 
Table 1. Comparison of traditional and new ways of delivering healthcare using the Internet. Adapted from Medical Profiling and online medicine: the ethics of personalised healthcare in a consumer age. Nuffield Council on Bioethics 2010. Nuffield Press, Oxfordshire

\begin{tabular}{|c|c|c|c|c|}
\hline $\begin{array}{l}\text { Healthcare } \\
\text { activity }\end{array}$ & Traditional method & New possibilities & Advantages & Disadvantages \\
\hline $\begin{array}{l}\text { Seeking health } \\
\text { information }\end{array}$ & $\begin{array}{l}\text { Health professional } \\
\text { Newspapers } \\
\text { Family } \\
\text { Friends }\end{array}$ & $\begin{array}{l}\text { Online search engines } \\
\text { Kitemarked Websites } \\
\text { \&"Internet prescribing" } \\
\text { Online communities } \\
\text { Forums/Facebook } \\
\text { User generated content } \\
\text { You Tube, Blogs }\end{array}$ & $\begin{array}{l}\text { Convenience } \\
\text { 24/7 information } \\
\text { Empowerment } \\
\text { Expert patient }\end{array}$ & $\begin{array}{l}\text { Incorrect information } \\
\text { Misinterpretation } \\
\text { Worried well } \\
\text { Threat to health professional } \\
\text { and therapeutic relationship }\end{array}$ \\
\hline Support & $\begin{array}{l}\text { Health Professional } \\
\text { Family } \\
\text { Friends }\end{array}$ & $\begin{array}{l}\text { Online communities } \\
\text { Forums, Facebook, } \\
\text { Messaging, Texting } \\
\text { User generated content } \\
\text { You Tube, Blogs }\end{array}$ & $\begin{array}{l}\text { Convenience } \\
\text { Wisdom of the crowd } \\
\text { Cost }\end{array}$ & $\begin{array}{l}\text { Incorrect information } \\
\text { Misinterpretation } \\
\text { Worried well } \\
\text { Threat to health professional } \\
\text { and therapeutic relationship }\end{array}$ \\
\hline Public Health & $\begin{array}{l}\text { Health Professional } \\
\text { TV } \\
\text { Radio } \\
\text { Paper advertising }\end{array}$ & $\begin{array}{l}\text { Twitter } \\
\text { Facebook } \\
\text { Websites } \\
\text { SMS texting }\end{array}$ & $\begin{array}{l}\text { Speed } \\
\text { Cost }\end{array}$ & $\begin{array}{l}\text { Digital Divide between the } \\
\text { 'haves' and 'have-nots' }\end{array}$ \\
\hline $\begin{array}{l}\text { Therapeutic } \\
\text { Interventions }\end{array}$ & & $\begin{array}{l}\text { Web sites } \\
\text { Apps and App prescribing } \\
\text { Facebook }\end{array}$ & $\begin{array}{l}\text { Being at home } \\
\text { Convenience } \\
\text { Cost }\end{array}$ & $\begin{array}{l}\text { Not been evaluated - may do } \\
\text { harm }\end{array}$ \\
\hline Patient records & $\begin{array}{l}\text { Hospital GP records } \\
\text { Maternity hand held } \\
\text { record }\end{array}$ & $\begin{array}{l}\text { Electronic health record } \\
\text { Emergency Patient Summary }\end{array}$ & $\begin{array}{l}\text { Storage } \\
\text { Available "anywhere" } \\
\text { Data mining }\end{array}$ & $\begin{array}{l}\text { Cost } \\
\text { Incompatibility of systems } \\
\text { Data entry burden }\end{array}$ \\
\hline
\end{tabular}




\begin{tabular}{|c|c|c|c|c|}
\hline & & & & Security \\
\hline $\begin{array}{l}\text { Obtaining } \\
\text { medication }\end{array}$ & $\begin{array}{l}\text { Over the counter } \\
\text { Medical prescribing }\end{array}$ & Web sites & $\begin{array}{l}\text { Being at home } \\
24 / 7 \text { availability } \\
\text { Convenience }\end{array}$ & $\begin{array}{l}\text { Inappropriate } \\
\text { Not genuine product } \\
\text { Inappropriate advice } \\
\text { Risk of Antibiotic resistance } \\
\text { Threat to health professional } \\
\text { and therapeutic relationship }\end{array}$ \\
\hline $\begin{array}{l}\text { Diagnosis, } \\
\text { monitoring and } \\
\text { management }\end{array}$ & & $\begin{array}{l}\text { Apps } \\
\text { Teleheath } \\
\text { Telemedicine } \\
\text { Remote consultations, } \\
\text { diagnosis monitoring and } \\
\text { management } \\
\text { prevention }\end{array}$ & $\begin{array}{l}\text { Being at home } \\
\text { Earlier transfer of care from } \\
\text { hospital to home }\end{array}$ & $\begin{array}{l}\text { Potentially intrusive } \\
\text { "surveillance of lifestyle" }\end{array}$ \\
\hline Incentivisation & $\begin{array}{l}\text { Health campaigns } \\
\text { Targeted groups for } \\
\text { awards }\end{array}$ & Social gaming & $\begin{array}{l}\text { Viral uptake } \\
\text { Individualised }\end{array}$ & Digital Divide \\
\hline
\end{tabular}


Figure 1. Formulating Healthcare

\begin{tabular}{|c|c|c|c|}
\hline$P 4$ & $\mathbf{C}^{\mathbf{n}}$ & $\begin{array}{l}\text { EIMT } \\
\text { electronic Internet Moblle Television Health }\end{array}$ & C \\
\hline $\begin{array}{l}\text { Personalised } \\
\text { Preventative } \\
\text { Participatory } \\
\text { Predictive }\end{array}$ & $\begin{array}{l}\text { Community } \\
\text { Co-development } \\
\text { Communicating } \\
\text { Crowd Wisdom } \\
\text { Co-production } \\
\text { Collaborating } \\
\text { Co-creating }\end{array}$ & $\begin{array}{l}\text { Health Web Science } \\
\text { and } \\
\text { Medicine } 2.0\end{array}$ & $\begin{array}{l}\text { Change } \\
\text { behaviour } \\
\text { environments } \\
\text { policy }\end{array}$ \\
\hline
\end{tabular}




\section{References}

1. RCOG. Why should we consider a life course approach to Women's Health Care. Scientific Impact Paper No 27, 2011.

2. Baggio G, Corsini A, Floreani A et al. Gender medicine: a task for the third millennium. Clin Chem Lab Med 2013; 51(4):713-27.

3. Kaminsky Z, Wang SC and Petronis A. Complex disease, gender and epigenetics . Ann Med. 2006;38(8):530-44.

4. Hackett JA, Sengupta R, Zylicz JJ et al. Germline DNA demethylation dynamics and imprint erasure through 5-hydroxymethylcytosine Science 2013;25;339(6118):448-52.

5. Barker, DJP. Maternal Nutrition, Fetal Nutrition, and Disease in Later Life. Nutrition 1997; 13:807.

6. http://p4mi.org/systems-biology

7. Shiao SPK, Yu CA, Xie C, et al. Data Analytics on Common Gene Mutations in Epigenetics Methylation Pathways: Population Health Issues for Cancer Prevention. 2015 AACR Computational and Systems Biology of Cancer conference, .

8. WHO. A life course approach to health. 2000.

http://www.who.int/ageing/publications/lifecourse/alc lifecourse training en.p df (last accessed 5/3/16)

9. Covolo L, Rubinelli S, Ceretti E, et al.. Internet-Based Direct-to-Consumer Genetic Testing: A Systematic Review. J Med Internet Res 2015;17(12):e279

10. McHattie LS, Cumming G and French T. Transforming Patient Experience: Health Web Science Meets Medicine 2.0. Med 2.0. 2014;3(1):e2 
11. Romana H-W. Is Evidence-Based Medicine Patient-Centered and Is PatientCentered Care Evidence-Based? Health Serv Res 2006;41(1): 1-8.

12. Elwyn G, Frosch D, Thomson R, et al. Shared Decision Making: A Model for Clinical Practice. Journal of General Internal Medicine 2012;27(10):1361-136.

13. Coulter A and Collins A. Making shared decision-making a reality. No decision without me. The Kings Fund 2011.

14. Pew Research Centre 2015. http://www.pewinternet.org/fact-sheets/healthfact-sheet/ (last accessed $17^{\text {th }}$ Nov 2015)

15. Van De Belt TH, Engelen LJ, Berben SAA, et al. Definition of Health 2.0 and Medicine 2.0: A Systematic Review. J Med Internet Res 2010;12(2):e18U

16. Cumming $\mathrm{G}$ and Currie $\mathrm{H}$. The Internet and the menopausal consultation: menopause management in the third millennium. JBMS 2005; 11: 103 -108

17. Cumming $\mathrm{G}$, Currie $\mathrm{H}$, Moncur $\mathrm{R}$ et al. A web based survey survey on the effect of menopause on women's libido in a computer literate population. Menopause International 2009; 15:8-12

18. Cumming GP, Herald J, Moncur R et al. Women's attitudes to hormone replacement therapy, alternative treatments and sexual health. Menopause International 2007;13:79-83

19. Cumming GP, Currie $\mathrm{H}$ and Moncur R.The effects of urinary incontinence and availability of publically accessible toilets: an online survey (Short Report) Menopause International 2011;17;14-15

20. Cumming GP, Currie $\mathrm{H}$, Moncur R et al. Web-based survey on the effect of digital storytelling on empowering women to seek help for urogenital atrophy. Menopause International 2010; 16:51-55

21. Cumming GP, Currie HD, Pannay N et alStopping HRT- were women ill advised? Menopause International 2011;17:82-87

22. (NG23) 2015. http://www.nice.org.uk/guidance/ng23

NICE guidelines

23.

Kahana E, Kahana B., Lovegreen L et al. The Proactive Aged: New Players in the Web World. Proceedings of Web Science 2011 Conference, Koblenz, Germany.Available http://www.websci11.org/program/.

24. Kahana B, Kahana E, Lovegreen $\mathrm{L}$ et al. Compensatory use of computers by disabled older adults. 
In Computers Helping People With Special Needs (766-769). Springer Berlin Heidelberg 2006.

25.

Luciano JS, Cumming GP, Kahana

E, et al. Health Web Science. Foundations and Trends ${ }^{\circledR}$ in Web Science. 2014 4(4), 269-419

26. Luciano,J.S, Cumming GP, Wilkinson MD et al. The emergent discipline of Health Web Science. J Med Internet Res 2013;15(8):e166

27. Denecke K.Health Web Science. Social media data for healthcare, 2015 Springer

28. $15 / 3 / 16)$ http://webscience.org/ (accessed

29.

observatoryl (accessed 15/3/16)

$\underline{\text { http://webscience.org/web- }}$

30. Hall W and Thanassis T Web Evolution and Web Science. Computer Networks, 56, 2012; (18), 3859-3865

31. Thanassis T, Hall W, Hendler J et al. 2014 The Web Observatory: a middle layer for broad data. Big Data, 2014;2,(3), 129-133

32. de la Torre-Díez I, LópezCoronado M, Vaca C, Aguado JS, et al. Cost-utility and cost-effectiveness studies of telemedicine, electronic, and mobile health systems in the literature: a systematic review. Telemed J E Health. 2015 Feb;21(2):81-5.

33. http://www.ndc.scot.nhs.uk/DataDictionary/SMR-Datasets/SMR00-Outpatient-Attendance/Virtual-Clinic/

34. (accessed 15/3/16) https://www.nodelays.co.uk/

35. Devlin AM, McGee-Lennon M , O'Donnell CA et al. Delivering Digital Health and Well-Being at Scale: Lessons Learned during the Implementation of the dallas Program in the United Kingdom. J Am Med Inform Assoc 2015;0:1-13

36. Bergmo TS. How to Measure Costs and Benefits of eHealth Interventions: An Overview of Methods and Frameworks. J Med Internet Res 2015;17(11):e254 
37.

The 2022 GP. A vision for General Practice in the future of the NHS. The Royal College of General Practitioners. 2013

38.

NICE guidelines

(NG23).Menopause: diagnosis and management. 2015

https://www.nice.org.uk/guidance/ng23 (accessed 15/3/16) 